\title{
Trends of organ donation and awareness in Ernakulam, Kerala
}

\author{
K Guleria*, AK Singh, B Kumar, P Agrawal, S Agrawal \\ From International Conference for Healthcare and Medical Students 2011 \\ Dublin, Ireland. 4-5 November 2011
}

\section{Introduction}

This study was conducted to get an insight into the knowledge, attitute and practice of the urban and rural poppulations of Ernakulam, Kerala regarding organ donation for transplantation.

\section{Methods}

A total of 500 people above 18 years of age of both genders were selected by convienent sampling in Kaloor and Njarrackal, Ernakulam, Kerala, Southern India. A pre tested semi structured questionnaire was designed about the knowledge, attitude and practice of the interviewees towards organs donation and this was done by door to door interview.

\section{Results}

Of the participants, in urban area $81 \%$ and in the rural area $85 \%$ had knowledge about organ donation. In the urban area $84 \%$ and in rural area $95 \%$ of the participants were pro-organ donation of that $76 \%$ in urban area and $78 \%$ in rural area are willing to donate organs for transplantation if required. Age, sex, money and occupation did not influence the attitudes. Out of those who are willing to donate; in urban area $78 \%$ and in rural area $81 \%$ were willing to donate for philanthropic reasons and rest if it was needed by their relatives. In urban area $6 \%$ and in rural area $10 \%$ of the participants had donated or pledged their organs.

\section{Conclusions}

According to our study awareness and attitude about organ transplantation seems to be good. Misconception regarding the organs that can be donated by living donors and those by cadaveric donation should be dispelled by creating more awareness regarding this. We can better try

Amrita Vishwa Vidyapeetham, India

C 2012 Guleria et al; licensee BioMed Central Ltd. This is an Open Access article distributed under the terms of the Creative Commons Attribution License (http://creativecommons.org/licenses/by/2.0), which permits unrestricted use, distribution, and reproduction in any medium, provided the original work is properly cited. to increase their knowledge by educational programs and provide sufficient information. Which can help in leading to improvement of the practice of organ donation.

Published: 9 July 2012

doi:10.1186/1753-6561-6-S4-P48

Cite this article as: Guleria et al:: Trends of organ donation and awareness in Ernakulam, Kerala. BMC Proceedings 2012 6(Suppl 4):P48. and take full advantage of:

- Convenient online submission

- Thorough peer review

- No space constraints or color figure charges

- Immediate publication on acceptance

- Inclusion in PubMed, CAS, Scopus and Google Scholar

- Research which is freely available for redistribution 